がこれは自然というものを対象にしているだけに，ひ そ゚く独創性のない，不自由な創造であると思われ勝ちで ある.ところが自由な創造という芸術がどれ程不自由な ものかは，例えば絵を見ればわかる，六れは与えられた 二次元の紙か布の上に，限られた種類の絵の具で描く.

しか子 19 世紀迄の絵は大体描かれんとするものは自然 (人体を含めて) である. Giottoから印象派に到る画家 の苦心は, 形, 色, 影, 光をいかにこの不自由な材料に より再現するにあったといってもよかろう。

物理学の発展が，原始的な擬人化から，もつと深い抽 象された概念にたりみなく進んでいることは当然である. しかし人間に作り出せる概念で，我々の経験を超絶した ものがあり得るわけはないから，自然=経験でない限り， 窮極の真理に到達し得るとは予期できない，我及の経験 は結局何かの形で神経細胞にマークされたものである. そして神経細胞の数は，極めて多いが，有限である。 そ の働きにもある一定の規則がある。 そうすれば人間に作 れるもので，卡う突飛なるのはあり得ない. surréalisme たって，夢とか，異労心理とかから preconscious 学捜し 出そうとしているのではないか. 人間の精神作用がこの ように限定されている以上，生物としての人間の発達か ら見て, 物理学の理諭が巡って来た途は, 或いは 11nique なものかもしれない, 幸にして, 物理学では, 最も正常
な経”験索材料としていながら，実験技術の不断の進歩に よって，末知の材料が後から後から現れて，理論家を忙 狆させている.

こんなまとまりのない話しをしていたのでは，いつ迄 たって为はてしがないから，標題に対する答えを記して 結論学導こう. 物理学では, 我々が経験から得られた概 念を抽象化し，それらを簡単な法則によって結でつけて， あらゆる自然現象を説明しようとする，厹の場合，どん な概念を用いるかは，必ずしも一義的にはきまらないか もしれない．例えば物が落ちるのを重力の働きとみるこ とには必然性はない，ある概念の下にできるだけ多くの 現象を説明し得るような理論を作ることは全く人間の創 造である.だから我々の自然に関する知識が広まるにつ れて, 理論の作りかえ，概念の精細化が常に必要になる. そして新しい創造は古いものをその中に包合しつ〉絶え ず坛がって行く. 自然=経験＝理論という方程式が満た されたとき，この操作は完了するであろう．气して我及 の神経細胞の有限なことは，人類の遺伝にまったく思い がけない突然变異が起らず，又人間が今後短い期間に原 水爆弾で全隇することがなければ，最後にはかなり十分 な程度に上の要求が満たされるようになるだあろう。一 一文字通りの超現実だの，神だのということを本気で考 えるような馬鹿なことをしない限り。

\title{
近代物理学に於ける説明
}

\section{Jean-Louis Destolches}

\begin{abstract}
Jean-Louis Destouches はンルボンヌ大学理学部教授で, 本稿は氏自身の許可在得て, 第 11 回国際哲
\end{abstract} 学会議論文集第 5 巻より訳出したるのである.

\section{I. 微視物理系の記述}

物理学者の考察の対象は《物理学》，即ち彼の意区によ って孤立せしめられ，時の経過に対して保存すると仮定 させらた宇宙の一部分，によって構成されている. 量子 物理学の通常の解釈によれば, 物理系 S は波動力学の法 則に従う粒子から成る。この系に関するどんな知識も， 我々の尺度の物理系で構成された適当な装置 $\mathfrak{A}$ を介し て行われる測定によってしか得られない，その際理論の 目的は，初発の測定結果から将来の測定結果についての 予測を計算することにある。これらの予測は確率によっ て表現せられ，確率は一般の予測理論の手続きにより波
動函数を介して計算せられる。般にこれらの予测は不 確実であって，零及び一とは異なる確率によって表現せ られる。

本質上次のように仮定せられる：1) 観測者は自ら選 んだ時期に自ら選んだ测定を行うことができる；2) 测 定の操作は，装置と被観测系との間に，通常の相互作用 の法則に従う相互作用を生ぜしめる.

もし物理学者に対象として選ばれた物理系 Sのみに着 目するならば，本質的不確定の規準により1)，それにつ

1) J. von Neumann, Gött. Nachr. 1929; ワルソー国際会議報告, 1938, 『物理学の新理論につレて』(Inst. Coop. Intellect. 1939) p. 32-34. P. Destouches-Février, 『物理学的理論の構造』 (Presses Universitaires, Paris 1952, p. 287). 
いて決定論的記述を与えることは不可能であること，即 ちこの系に関する隠された決定論の理論は，常に経験と 一致する予测を与えた波動力学と同じ予測を提示するこ とはできないこと，が知られている；系 Sに関する隠さ れた決定論の理論, 即ち一定の状相空間に於ける点状図 式，は従って不適格の理論であるだろう. 或は波動力学 の局部的一理論と同等であるだろう.

\section{II. 波動力学よりも完全な理論2)及び優った理論3)}

ぬし Einstein と共に波動力学は不完全な理論である と考觉て，波動力学では知られないが時として経験に接 近し得るような量を介大せしめることによってこれを補 足しようと努めるならば，波動力学と同じ構造を持ち且 つ同様に本質的に補足不可能で非決定論的である新しい 理論を得るだろう. 波動力学よりあ完全であって, 闒じ た図式を構成するために形而上学的量に頼らない理論は， すべて波動力学と同様に開いたま〉に止まっている.

また，波動力学よりも優れた理論，即ち普通の量子理 解よりも大きな適応領域を持つ理論を丵成することを提 筜することもできる.このような理論が波動力学に取っ て替るためにはそれは，波動力学の適応領域に於いて， Heisenberg の不確定関係に従うこの力学によって与え られる予测に非常に近い予测を提示することが必要であ る. 新しい理論では下方の限界は多少違って来るか子知 れない方零ではあり得ない. 従って本質的非決定論の規 準が当てはまり，この適応条件に従う新しい理論は必然 的に量子理諭の構造を持つであろう.

\section{III． 測定の手続きに參与する系の記述}

波動力学は测定の手続きの詳細を敍述しないけれども， von Neumann 氏ゔしたように，系Ｓと测定装置との 速結によって形成される系 $\left(\mathrm{S}+\mathfrak{H}_{A}\right)$ を被観則系と見な すことによって，この手続きを明示することができる. この新しい系は，微視的観点から敘述せられる時には量 子法勋に往う。

また一少，装置 $\mathfrak{A}_{A}$ を介して测定せられる系 $\mathrm{S} を ， \mathfrak{A}_{A}$ が測定装置であるという事実がそこで本質的役割を演ず る一つの対 $\left(S / \mathfrak{A}_{A}\right)$ として考光ることができる.この場 合には，一たび装置 $\mathfrak{U}_{A}$ が選ばれ測定が始められたなら

2) P. Destouches-Février, 『量子理論の開かれた構造』Revue phil. 1952 年 7 月, p. 369 .

3) J. L. Destouches, 『物理学者にして思想家の Louis de Broglie』 の中，過去への復㷌 (Albin Michel, Paris, 1952) p. 83.
ば，観測者はもはや，参与する実験手続きの系列につい て決して勝手な配置をしない。この実験手続きはたた一 つの量，即方用いられる装置 $\mathfrak{A}_{\alpha}$ によって定義され見か け上の状態量となる量 $A$ ，の值を提示し得るのみだ, 従 って構成し得ない量は現れることができず, 系 $\left(\mathrm{S}+\mathfrak{A}_{A}\right)$ は観测手続きと烈関係に定まる対象として展開する，气 の際これについて決定論的記述を与えることができるが， しかしそれは経験には原理的に接近できない量に頼ると いう条件の下に於いてである. 事実ただ一つの最 $A$ を 考光る場合には，常に系 $\left(\mathrm{S}+\mathfrak{U}_{A}\right)$ に対して状相空間 $(\mathrm{R})$ に於いて少くとも一つの精確な一対一の变換が存在し， この精確な変換の下にこの状相空間内の諸点の運動から, 即ち波動力学と同じ予测を与える客観主義的決定諭的図 式に於ける諸点の運動から，量 $A$ に対する確率が表現 せられることになる．しかしこのような図式に導入しな ければならない接近不能の諸量は実証の精神に反する形 而上学的性格をるつ.

かくして我及は次のような可能事項の前に立つ：

1) 考察せられる物理系 $S$ に関しては，特殊の测定手 続き即ち系をその下に置くように決めることのできる特 殊の測定手続きとは䍢関係に，本質的非決定論の規準が 満たされる.

2）決定された测定手続きに参与する系に関しては理 諭構造の幾つかの試みを考えることができる：

a) 現象論的非決定諭的である統計的に解釈された波 動力学;

b）より一層完全であるために波動力学にとって未知 の最に頼る理諭; それは波動力学と同じ構造, 同じ特忙 を持つだろうことを示すことができる；

c）波動力学よりも優れた理諭；之れは同様に開かれ て㧍り非決定諭的であるだろう;

d）経験に接近できない架空の量の導入によって客镜 主義的決定論的な閉じた図式を構成する理論；これらの 量の或るものが他日測定可能になったとしても，その理 論が客観主義的図式を構成するためには常に接近不能量 の力を借りなければならないだろう．かくしてこのよう な理論は実証の精神と相容れない形而上学的考察に助け を求める.

\section{IV 測定放亲の場合に於ける物理系の記述}

系 $\mathrm{S}$ を装置 $\mathfrak{U}_{A}$ によって测定する代りに，観測者が 時間 $\left(t_{0}, t_{1}\right)$ のあいだ全然測定をしないと決心するなら 纺，系の展開は観測者と無関係のま〉である；この事実 
から彼は系の展開についてこの時間のあいだ客観的記述 を与えることができる; 経験を放寨しょうと決めたのだ から，どのような経験もこの記述に反することはないだ ろうし，同じ事情に置かれた凡ての物理系 $(\mathrm{S}+0)$ につ いてそうである。この事実から観测者は測定の期間を除 いた系の総体について客観的な記述即ち世界の表示, 《Weltbild》，を構成することができる。しかしかの測定 を実行しょうと決心する場合と同様に，あらゆる測定を 放棄しょうと決心することによって観测者は系に対して 有していた随意性を断念し，かくして客観主義的記述を 可能にする.この客観主義的記述は必然的に宇宙総体に ついての理諭即ち宇宙論であるだらう，何となれば完全 な放稁の場合には研究している粒子の運動について何も 知らないのて観測者は粒子を宇宙の中に描写するに至り， そして宇宙総体の理論は客観主義的な, 従って決定論的 な理論であるからである。

測定を実行劣る場合とは区対に，統一理論（一般相対 性）に於いては，この客観主義的述は全く根拠のないる のではない，何となれば《世界像》の相互関聯性の諸条 件によって提示せられる諸関係は実験的反響を持つであ ろうからである。これらの諸関係は微視物理系の特性に 於いて客観化せられ得るもの, 即ち粒子の種類を特徵づ ける一種の量及び力の法則, に関する. 幾つかの統一理 諭が可能であること，及びこれらの理論の多数性はそれ らがわ心らす結果の確実性を減ずることになることを注 意しょう。

\section{V. 種々の記述の実現}

波動力学の物理的解粕文改善与る目的で考案孙られた 新しい理諭の中で今日をでに提出せられた最女興味深い 为のは, 1527 年以来 Louis de Broglie 氏によって発 見せられ㤂二重解をるつ榔導波の理論である。

他方に於いて現象論的見透から導かれた粒子概念の批 判的吟味は粒于の函数的概念に到達する：粒子はもし自 由な可変の一点 M によって幾何学的に画かれるならば, 最も一般の場合には物理的にこれをかような一点によっ て画くことはできない: それは無限数の媒介変数によっ て, 或は更に一つの函数凹によって敍述されなければな らない；かくして粒子文は粒子系の三波動説を生ずる.

一方では粒子を敘述するための物理波 $u(P, T)$ がある； 幾何学的に粒子は $u$ の函数即ち $\mathrm{M}=\operatorname{sing} u$ なる一点 $\mathrm{M}$ によって表示せられる；他方では粒子についての予測を 可能にする予測波 $X(u, t)$ がありこれは函数空間, 即ち
函数 $n$ の空間に於いて変位する波動である; 最後に幾何 学的秩序の予測は $X(u, t)$ から計算される函数 $\Psi(M, t)$ によって表現せられるだろう. 波動力学の適応領域に於 いては函数 $\Psi$ は波動力学の波動函数 $\phi$ 之区別がつか ない. かくして純粋に現象論的な観念によって粒子の函 数的一般理諭に到達する. この理論では物理波 $u$ は決 定論的な為方で展開しないで, 波動力学的の粒子を表象 する自由な可変の点 $M$ として振舞う．この理諭は本質 的に非決定諭的であって，このことは実際，波動力学よ り優れたどんな理論にも課せられる一般的条件に合致し ている.

しかし観測者が，ぞのような測定が実施されようとし ていたかを確定した時, 或は定まった時間の間凡ての測 定を放亲する時, 客観主義的記述が可能である. 今度は 粒子を表象するものは波動 $u$ である. 波動 $u$ はこの場合 実在論的, 客観主義的, 決定諭的な為方で敘述されなけ ればならない; それは時の経過と共に定まった為方で展 開するだろう，測定がない場合にはそれは宇宙総体の中 で敍述されなければならないだろう。そこでこのような 記述が提出せられた：それはVigier 氏の統一理論的記 述を伴う Louis de Broglie 氏の二重解のそれである. かくして我々は三つの観点の合流点にある：Louis de Broglie 氏の二重解の理論, 実在論的相対諭的統一理論, 現象論的三波動理論. るし三波動理論から出発するなら ば，客観主義的表示はそれについての二重解の理論でな ければならないことが分る；もし二重解の実在諭的理論 から出発して, 接近不能の量を排除する現象論的理諭に 達しようとするならば，三波動の理論に導かれる。

常用の量子理諭と一般化せられた相対論的理諭とは矛 盾する;この場合に統一は相補性を誘導する：乏れはま さしくそうなるべきものであって，宁宙と系との相補性， 或は更に実在論的側面と現象諭的側面との間の相補性が 現れる：一つの側面と他の側面とでは物理系の概念は同 一でない: 一つの場合には $\mathrm{S}$, 他の場合には $\left(\mathrm{S}+\mathfrak{A}_{A}\right)$ 㕛は $(\mathrm{S}+D)$ である. 純粋に古典的な観点に帰ることは できない: 量子理論を古典理論から区別する構造上の特 性があり，これは実在論的記述を採用しても必然的に見 出されなければならないものである。

物理学の二つの大きな理論の統一は常に多くの新しい 関係を招来する; 統一する理論は常に, 統一すべき二理 論の適応領域の併合よりも大きな適応領域をもっている. かくして今や，非常に豊かな収穫を期待される理論物理 学発展の新しい時代が始まっている. 


\section{VI. 認識論的註}

今述べた客観主義的決定論的理論の樹立は物理学に於 ける実在論への復帰を標示する. しかし形而上学的観念 に訴えているのだから，测定できる媒介变数々接近でき ない媒介变数との間の差異を解釈する必要があるだろう。 実在論型の理論は，我々の認識する手段と無関係な客体 の記述として提起される；これに反して現象諭的観点で は，《在るもの》に心を奪われることるなく，それ自身で 存在する何ものか，即ち客体が，あるかどうかを知ろう とさえもしないで，専ら知っているもの即ち知識のみを 目指市.

現象論者は実在論的理論の形而上学的性格を言い立て る;しかしこれは実在論的理論からそれの利益を奪わな い，なぜならそれは現象論的記述が示唆することのでき ない諸関係の発見を可能ならしめることによって発見的 価值を持ち得るからである.

実在論者は実証主義的理論の不生産性を言い立てる， しかしこれは歴史的に常に正しくはない；例えば実在論 及び理想主義によって薷らされたニュートン力学は現象 主義的精神の捻て蒙を啓かれた；また，矛盾によって 㵐痺状態に陥った XIX 世紀の古典原子説に対してエネ ルギー説を樹立し，そこから熱力学応用の著るしい抎張 を招来したのは実証主義である；なお，Einstein を特殊
相対性理論の建設に導き，また最後に，実在論的試みが 首尾一貫した結果に到達しなかった際に堅固な基碟の上 に量子理論を建設したのも現象主義的志向だある.

これに反して実在論は Newton にその力学の樹立を 可能ならしめ, XIX 世紀の原子論者に物質の運動理論 の建設を，この世紀の初頭の実験学者に分子，原子，素 粒子の実験的証明を, Einstein に一般相対性理論の建設 を可能ならしめた；今やそれは相対性と量子との統合に 向って進むことを可能にする.

交互に，そして解くべき間題に応じて，実証主義と実 在論とが研究に霊感を与えるように見える. 実在論のみ が新しい関係，新しい表示を提供することができ，これ に反して実証主義のみが非常に厳正な批判によって矛盾 の除去と満足な形の理論の建設とを可能にするように思 われる. 《私は科学を基楚づける努力と科学を建設する 努力との間にはどうも実際上或る対立があるのではない かと思う》と Gaston Bachelard は書いているせ). 上述 のように相対抗しているこれら二つの傾向の有効な実現 は，一たびその対立が，之れらの相補的性格を発現せし める《Aufhebung》によって乗り越えられるならば, 実り豊かな結果への道を開くことができるだろう。

(堀 伸夫訳)

4) 科学哲学の国際会議の記録, (IIermann, Paris, 1951, Act. Sc. et ind., fasc. 1126, p. 34).

\section{バターフィールド「近代科學の起源」1300〜1800}

H. Butterfield, The Origins of Modern Science 1300 1800. 1949. London, G. Bell and Sons Ltd, p. p. $\times+213$.

古田光

\section{I}

科学々歴史の関係を明かにすることによって，自然科 学と人交科学の間の架橋たるべく期待されながら，事実 はなお雨者の間を中途半端にさまようているというのが， 科学史研究の現状であろう，現在の科学史は現代の要求 にはいささか遅れている. しかも科学の歴史的理解とい うことの重要性は, 科学者にとっても歴史家にとっても しだいにはっきりと意識されてきているようである。か かる現状において，たんに科学史のみの専門家ではないい わゆる“genera1 historian”が, しかも史学界の名門Ca- mbrige の現役教授が, 本書のようなまとまった科学史的 労作を発表するにいたったという事実そのものが，まず われわれの興味をひく点であろう. 本書の著者 Herbert Butterfield の名は, Christianity and History (1949). History and Human Relations (1951), Christianity in European History (1951) などの著作により，Dawson, Toynbee らにひきつづき 20 世紀イギリス史学の 生んだ俊英の一人として, 戦後のヨーロッパ人の耳には すでに親しいものとなっている. 戦前にも The Historical Novel (1924) The Whig Interpretation of History (1931), Napoleon (1939), The Statekraft of 